\title{
New and old records of Euglossa imperialis Cockerell, 1922 (Apidae, Apinae, Euglossini) for the Amazon rainforest, Cerrado, and Pantanal of Mato Grosso, Brazil
}

\author{
Marta Helena Schorn de Souza ${ }^{1,2}$, Evandson José dos Anjos-Silva ${ }^{1,2}$ \\ 1 Universidade do Estado de Mato Grosso, Departamento de Biologia, Laboratório de Abelhas e Vespas Neotropicais, Av. São João, 563, Cáceres, \\ Mato Grosso, 78.200-000, Brazil. 2 Universidade do Estado de Mato Grosso, Programa de Pós-graduação em Biodiversidade e Biotecnologia, \\ Rede Bionorte, Av. Fernando Correa da Costa, 2563, Cuiabá, Mato Grosso, 78.060-900, Brazil. \\ Corresponding author: Evandson J. Anjos-Silva, evandson@unemat.br
}

\begin{abstract}
Euglossa imperialis Cockerell, 1922 has recently been catalogued in the Cerrado of Mato Grosso do Sul, Brazil, and here we add both new and old data obtained from expeditions conducted in 10 municipalities of Mato Grosso since 2002. In this study we record this species for the first time in the wetlands of Cáceres and Barão de Melgaço, as well as on the northern Pantanal. Further studies are required to examine the variation in the coloration and other characteristics in E. imperialis populations from the northern and southern floodplains.
\end{abstract}

\section{Keywords}

Dispersal corridor, distributional gaps, dry forest, euglossines, gallery forest, orchid bees, wetlands.

Academic editor: Filippo Di Giovanni | Received 18 June 2019 | Accepted 14 February 2020 | Published 13 March 2020

Citation: Schorn de Souza MH, Anjos-Silva EJ (2020) New and old records of Euglossa imperialis Cockerell, 1922 (Apidae, Apinae, Euglossini) for the Amazon rainforest, Cerrado, and Pantanal of Mato Grosso, Brazil. Check List 16 (2): 243-252. https://doi.org/10.15560/16.2.243

\section{Introduction}

Belonging to the family Apidae and to the tribe Euglossini, the corbiculate bees of the genus Euglossa Cockerell, 1922 are represented by 140 described, valid species subdivided into seven subgenera: E. (Euglossa) Latreille, 1802, E. (Glossura) Cockerell, 1917, E. (Euglossella) Moure, 1967, E. (Dasystilbe) Dressler, 1978, E. (Glossurella) Dressler, 1982, E. (Glossuropoda) Moure, 1989 (see Ramírez et al. 2002), and E. (Alloglossura) Hinojosa-Díaz and Engel, 2012 (Hinojosa-Díaz and Engel 2012a).

The subgenus Glossura is represented by 16 species characterized by a) the scutellum biconcave, b) extremely elongated mouthparts apparatus, reaching beyond the tip of abdomen, c) labrum greater in length than in width, and d) male midbasitarsus with internal keel. The internal keel is an important feature of E. piliventris Guérin-Méneville, 1845 and E. imperialis Cockerell, 1922 (Dressler 1978; Rebêlo and Moure 1995; Moure et al. 2012), the latter being the species addressed in the present study.

The publication of species' distributional data in specialized entomological journals and books contributes to our knowledge of species occurrences. It is irrefutable, however, that many data remain unpublished and, therefore, unavailable, which results in the persistence of numerous biogeographical gaps in the distribution. Such is the case of E. imperialis, a species of long-tongued euglossine bee of the subgenus Glossura. 
Euglossa imperialis presents a large range of geographic distribution and has been reported from southern México (Chiapas, Quintana Roo, Veracruz) to Honduras (McCravy et al. 2016), Costa Rica, Nicaragua, Panama, Colombia, Ecuador, and Peru (Janzen et al. 1982; Ackerman 1983; Zimmerman and Madriñan 1988; Roubik 1993; Eltz et al. 1999; Otero and Sandino 2003; Roubik 2004; Roubik and Hanson 2004; Moure et al. 2012; Hinojosa-Díaz and Engel 2012b; Padrón et al. 2018). It has also been catalogued from Brazil (Moure 1989; Becker et al. 1991; Rebêlo and Garófalo 1991; Rebêlo 1993; Rebêlo and Moure 1995; Rebêlo and Silva 1999; Nemésio and Faria Junior 2004; Darrault et al. 2005; Anjos-Silva 2006a, 2006b, 2011; Faria Junior and Melo 2007; Oliveira et al. 2010; Schorn de Souza 2014; Figueiredo et al. 2015; Mateus et al. 2015; OliveiraJunior et al. 2015; Antonini et al. 2017; Tosta et al. 2017; Cândido et al. 2018; Henrique et al. 2018; Coswosk et al. 2018; Machado et al. 2018).

In Brazil, this species has been catalogued from the Amazon rainforest (Moure 1989; Becker et al. 1991; Rebêlo and Silva 1999; Anjos-Silva 2011; Antonini et al. 2017; Cândido et al. 2018), the Cerrado (Rebêlo and Garófalo 1991, 1997; Rebêlo 1993; Rebêlo and Moure 1995; Nemésio and Faria Junior 2004; Anjos-Silva 2006a, 2006b, 2011; Oliveira et al. 2010; Schorn de Souza 2014; Figueiredo et al. 2015; Oliveira-Junior et al. 2015; Tosta et al. 2017; Henrique et al. 2018), besides the marine alluvial fan in Maranhão (Rebêlo and Silva 1999), the Pernambuco center of endemism (Darrault et al. 2005) and the Atlantic forest (Faria Junior and Melo 2007; Mateus et al. 2015; Coswosk et al. 2018; Machado et al. 2018).

Despite all the information available to date on the geographic distribution of E. imperialis, this species is unreported in the literature from southern Amazon to central Brazilian Cerrado. Especially when one considers the vast extent of the Amazon forest and the central Brazilian Cerrado domains and their diverse habitat conditions, it is evident that more studies are required. Here we bring data obtained by our research group in surveys conducted over the last 16 years in 10 regions within the Amazon, Cerrado, and Pantanal of Mato Grosso. All the specimens are deposited at the UNEMAT Bee Collection (EJASC) and are available to the public and specialists, as required.

Due to this lack of distributional data of this species in these areas, both authors checked all the specimens housed from 2002 to 2019 in the UNEMAT Bee Collection to start work on the current paper, and here we present the results of the surveys conducted in the Amazon-Paraguay divide.

\section{Methods}

Male orchid bees were caught in the legal reserve area of the Instituto Federal de Educação, Ciência e Tecnologia (IFMT) at the São Vicente campus $\left(15.8226^{\circ} \mathrm{S}\right.$, $055.4184^{\circ} \mathrm{W} ; 750 \mathrm{~m}$ altitude), in the Santo Antônio do
Leverger municipality, Mato Grosso (Figs 1, 2). The region characterized by a Tropical Savanna climate, Aw type on the Köppen-Geiger climate classification system (Peel et al. 2007).

The collections were performed monthly for three consecutive days, from November 2016 to June 2018, between 8 a.m. and 4 p.m., totaling 60 days of surveys, or 480 hours of direct observation of the bees in field surveys throughout the 20 -month period. The expeditions had been granted permission to collect insects under ICMBio SisBio license numbers 12.778 and 18.147-2 in the name of EJAS.

Four pure chemicals were used throughout the surveys: $\beta$-ionone, 1,8 -cineole, methyl salicylate, and vanillin. The males were caught with the use of entomological nets, sacrificed in ethyl acetate, and identified by a team member (Evandson José dos Anjos Silva). The specimens are housed in the Mato Grosso State University (UNEMAT) Bee Collection (EJASC, E J Anjos-Silva collection) of the Laboratory of Neotropical Bees and Wasps (LABEVE), at the Cáceres campus, Mato Grosso, Brazil. The systematic and morphological terminology follows that of Michener (2007) and Engel (1999, 2001).

In this study the geographic distribution of E. imperialis is discussed following the inclusion of the material deposited in the UNEMAT Bee Collection and obtained from a series of expeditions made from 2002 to 2018 (Fig. 3), together with unpublished monographs, dissertations and theses written by our team.

\section{Results}

\section{Euglossa (Glossura) imperialis Cockerell, 1922} Figure 4

New records. BRAZIL - Cerrado • $1 \delta^{\lambda}$; Mato Grosso, Chapada dos Guimarães National Park; $15.4088^{\circ} \mathrm{S}$, 055.8322 ${ }^{\circ}$ W; $630 \mathrm{~m}$ a.s.1.; 2 Sep. 2003; Anjos Silva EJ leg.; 1,8-cineole; gallery forest; EJASC 0167. • 1万人; ibid; 4 Nov. 2003; 1,8-cineole; EJASC 0259. • 1ठ; ibid; 4 Nov. 2003; vanillin; EJASC 0269. • 1ठ;; ibid; 12 Jan. 2004; 1,8-cineole; EJASC 0371. • 3ð̧; ibid; 4 Jul. 2004; 1,8-cineole; EJASC 0534, 0544 and 0548. • 2ふ઼; ibid; 17 Sep. 2004; methyl salicylate; EJASC 0602 and 0604. • 6今; ibid; 10 Oct. 2004; methyl salicylate; EJASC 0610, 06120616. • 1ठ; ibid; 11 Oct. 2004; 1,8-cineole; EJASC 0617. -3今̄; ibid; 12 Dec. 2004; methyl salicylate; EJASC 0954, 0956, 0958. • 1今ं; ibid; 21 Mar. 2005; methyl salicylate; EJASC 2865. • 1ठ; ibid; 3 Apr. 2005; methyl salicylate; EJASC 3285. - 23 $\hat{\text {; }}$ ibid; 3 Apr. 2005; 1,8-cineole; EJASC 3286-3309. • 6今; ibid; 13 Apr. 2005; methyl salicylate; EJASC 3165-3170. • 1ठ̂; ibid; 22 Jul. 2005; methyl salicylate; EJASC 3636. • 1ठ; ibid; 2 Aug. 2007; methyl salicylate; EJASC 20.163. • 1ðَ; ibid; 8 Aug. 2007; methyl salicylate; EJASC 20.162. • 4ðึ; ibid; 22 Nov. 2007; methyl salicylate; EJASC 20.158-20.161. • 1ठ; Mato Grosso, Cáceres; $16.0223^{\circ} \mathrm{S}, 057.6656^{\circ} \mathrm{W} ; 120 \mathrm{~m}$ a.s.1; 2 Jul. 2007; Anjos Silva EJ leg.; 1,8-cineole; EJASC 


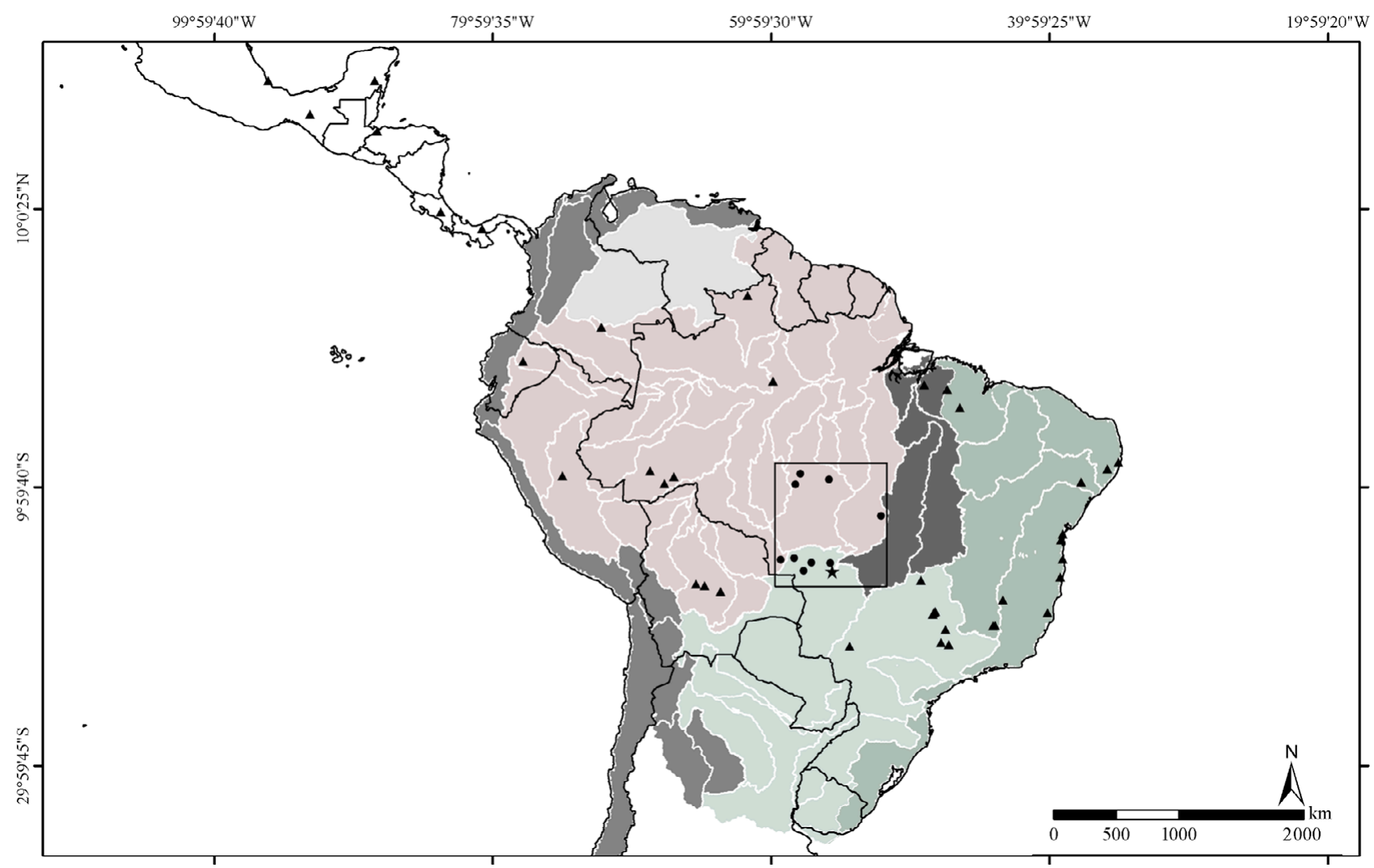

Figure 1. Map of geographical distribution of Euglossa imperialis Cockerell, 1922 (Apidae, Euglossini), with indications of the collection points of specimens from south Mexico to southern Atlantic forest. Black triangles indicate the occurrences of the species recorded in the literature consulted. Black circles indicate the records of individuals in the UNEMAT bee collection (EJASC). Black star indicates the new occurrence of this species at the northeastern edge of the Mato Grosso Pantanal.

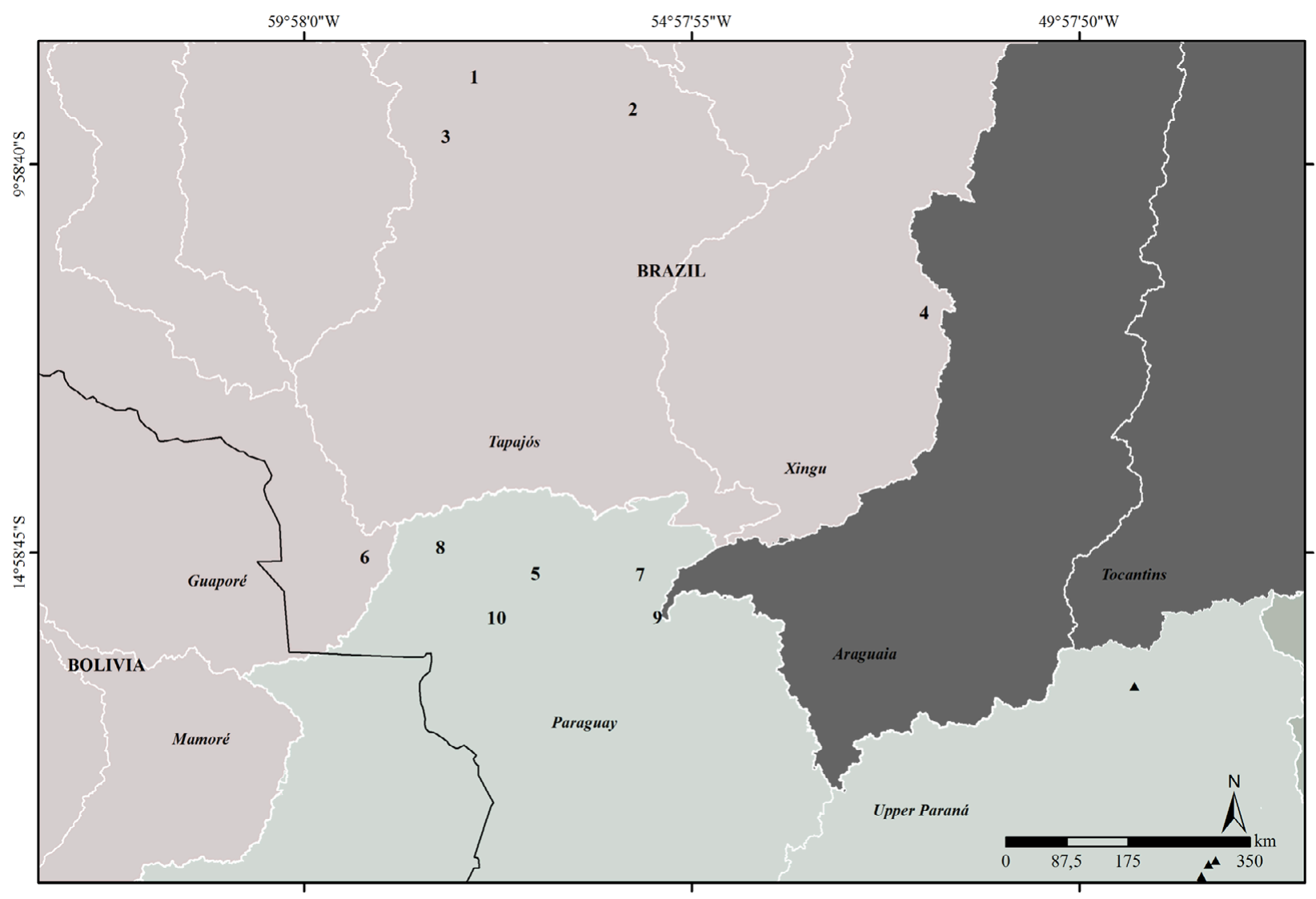

Figure 2. Details of the Amazon-Paraguay drainage divide in Mato Grosso, Brazil. Black triangles indicate previous records. Study areas: 1 = Apiacás, 2 = Novo Mundo, 3 = Cotriguaçu, 4 = Ribeirão Cascalheira, $5=$ Reserva do Cabaçal, $6=$ Pontes e Lacerda, $7=$ Chapada dos Guimarães, 8 = Porto Estrela, 9 = Santo Antônio do Leverger, 10 = Cáceres. 

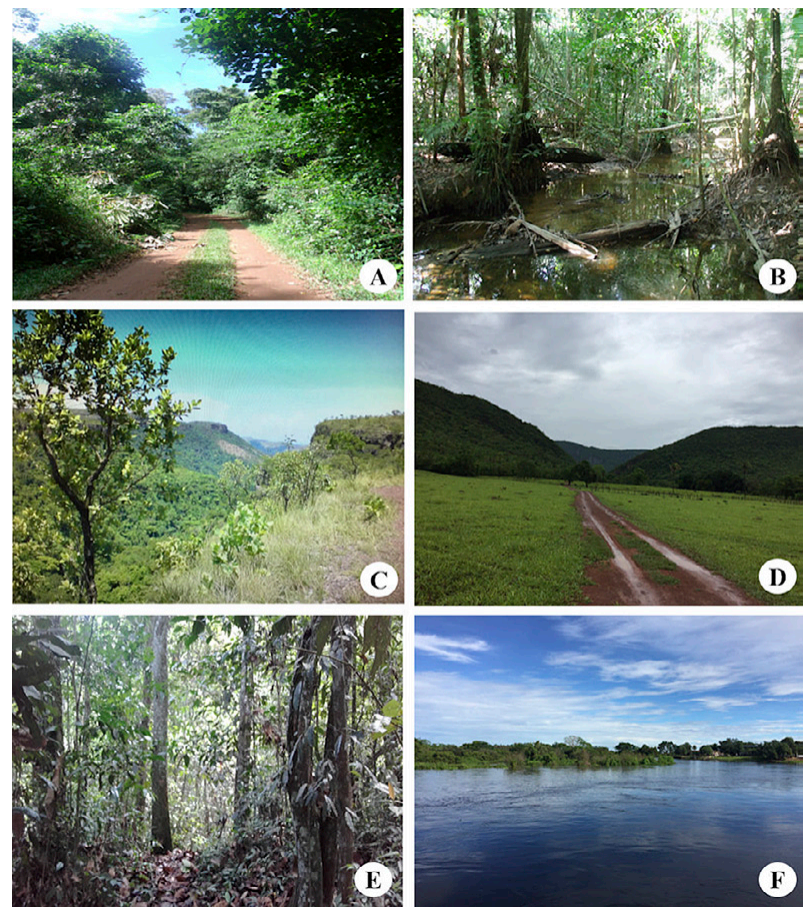

Figure 3. Study areas in Mato Grosso, Brazil. A. Novo Mundo. B. Cotriguaçu. C. Chapada dos Guimarães. D. Porto Estrela. E. Santo Antônio do Leverger. F. Cáceres.

20.154. • $1 \delta^{\Uparrow}$; Mato Grosso, Porto Estrela, Serra das Araras; $15.4527^{\circ} \mathrm{S}, 057.1013^{\circ} \mathrm{W} ; 230 \mathrm{~m}$ a.s.l.; 18 Apr. 2011; Cunha JC leg.; methyl salicylate; gallery forest; EJASC 30.481.・1ðं; ibid; 13 Sep. 2011; methyl salicylate; EJASC
35.430.・1 ${ }^{\text {; }}$; ibid; 8 Sep. 2011; methyl salicylate; EJASC 35.456 - 7ठ̊; ibid; 8 Sep. 2011; 1,8-cineole; EJASC 35.449-35.455. • 2§; ibid; 27 Mar. 2011; 1,8-cineole; EJASC 30.482-30.483. • 7ô; ibid; 15 Sep. 2011; methyl salicylate; EJASC 35.423-35.429. • 4ð̊; ibid; 10 Sep. 2011; methyl salicylate; EJASC 35.445-35.448. • 14 ibid; 10 Sep. 2011; 1,8-cineole; EJASC 35.431-35.445. • 17ふै; ibid; 14 May 2011; methyl salicylate; EJASC 30.464-30.480. • 7ðં; ibid; 14 May 2011; 1,8-cineole; EJASC 30.457-30.463. • 6ð’; Mato Grosso, Santo Antônio do Leverger, Serra de São Vicente; $15.8226^{\circ} \mathrm{S}$, 055.4184 W; $750 \mathrm{~m}$ a.s.1.; 16 Nov. 2016; Schorn de Souza MH leg.; methyl salicylate; gallery forest; EJASC 50.768-50.773. • 50⿱㇒ ; ibid; 16 Nov. 2016; 1,8-cineole; EJASC 50.774-50.778. -23; ibid; 17 Nov. 2016; 1,8-cineole; EJASC 50.854-50.855. • 12ð’; ibid; 17 Nov. 2016; methyl salicylate; EJASC 50.856-50.867. • 2ふ; ibid; 12 Dec. 2016; 1,8-cineole; EJASC 50.950-50.951. • 2ో; ibid; 12 Dec. 2016; methyl salicylate; EJASC 50.95250.953. • 4ð; ibid; 14 Dec. 2016; 1,8-cineole; EJASC 50.967-50.970. • 2万; ibid; 13 Dec. 2016; methyl salicy-

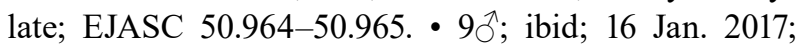
methyl salicylate; EJASC 65.735-65.743. • 1ðð; ibid; 16 Jan. 2017; 1,8-cineole; EJASC 65.734. • 4ð̊; ibid; 17 Jan. 2017; methyl salicylate; EJASC 65.746-65.749. • 23; ibid; 17 Jan. 2017; 1,8-cineole; EJASC 65.744-65.745. • 3 ’’; ibid; 18 Jan. 2017; methyl salicylate; EJASC 65.75065.752. • 1ठ; ibid; 18 Jan. 2017; 1,8-cineole; EJASC 65.753. - 10 ; ibid; 15 Feb. 2017; methyl salicylate; EJASC 65.790-65.799. • 2ठ; ibid; 15 Feb. 2017;

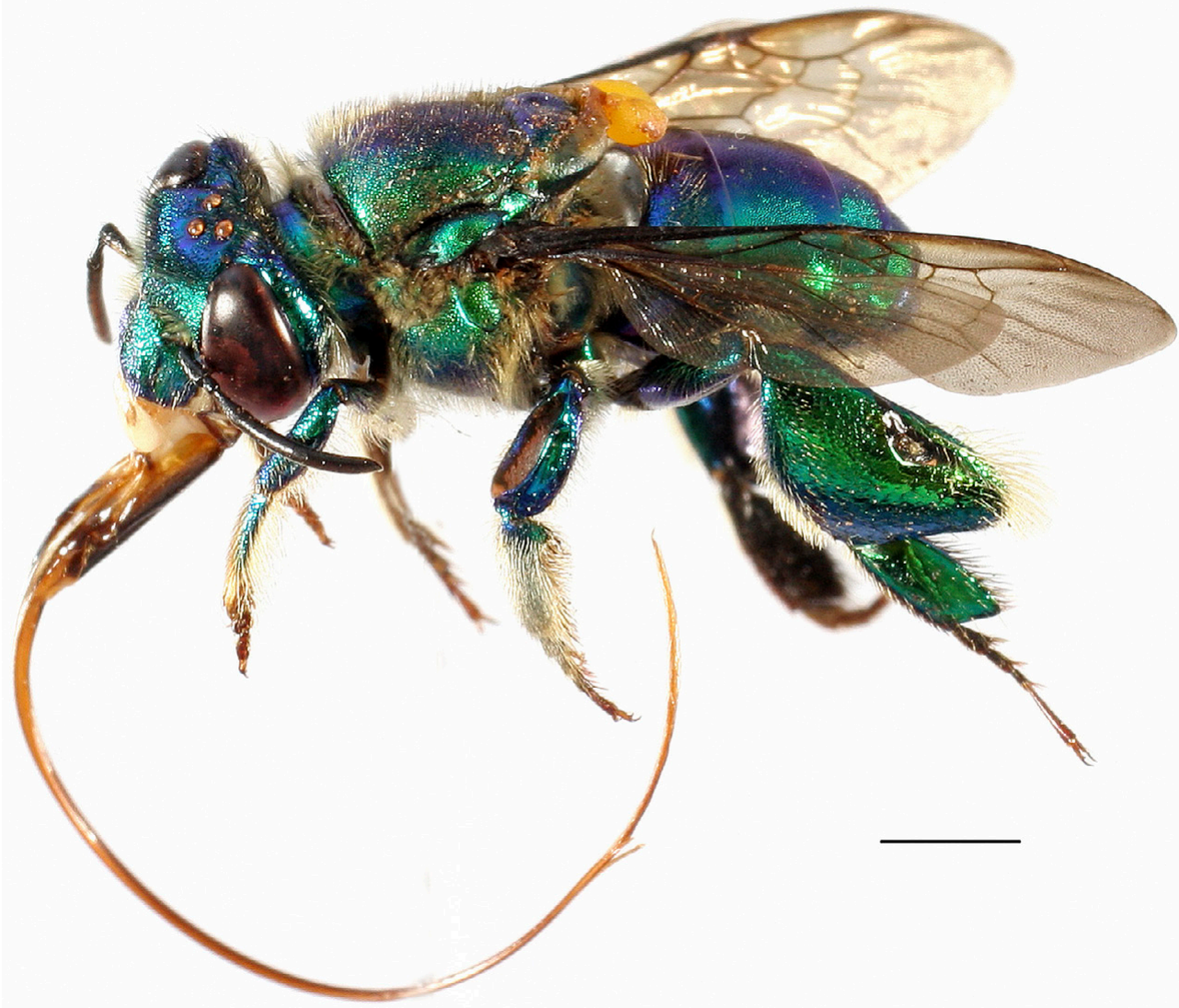

Figure 4. Lateral habitus of the male of Euglossa imperialis Cockerell, 1922 from Chapada dos Guimarães National Park, with pollinarium of a native orchid (Orchidaceae) attached to the mesoscutellum (EJASC 3167). Scale bar $=2 \mathrm{~mm}$. 
1,8-cineole; EJASC 65.800-65.801. • 10; ibid; 16 Feb. 2017; methyl salicylate; EJASC 66.802. • 10त्र; ibid; 22 Mar. 2017; methyl salicylate; EJASC 66.858-66.867. • 6ð̊; ibid; 22 Mar. 2017; 1,8-cineole; EJASC 66.86866.87380.710. • 10 $\overbrace{}^{1}$; ibid; 23 Mar. 2017; methyl salicylate; EJASC 66.874-66.883. • 3 ${ }^{\lambda}$; ibid; 23 Mar. 2017; 1,8-cineole; EJASC 66.884-66.886. • 6ð; ibid; 24 Mar. 2017; methyl salicylate; EJASC 66.887-66.892. • 1ठ; ibid; 24 Mar. 2017; 1,8-cineole; EJASC 66.893. • 7ð̋; ibid; 17 Apr. 2017; methyl salicylate; EJASC 66.90066.906. • 10َ; ibid; 17 Apr. 2017; 1,8-cineole; EJASC 66.907. • 8 ; ibid; 18 Apr. 2017; methyl salicylate; EJASC 66.908-66.915. • 1ठð; ibid; 18 Apr. 2017; 1,8-cineole; EJASC 60.916. • 5ふ⿱亠丷 ; ibid; 19 Apr. 2017; methyl salicylate; EJASC 66.917-66.921. • 2ð; ibid; 19 Apr. 2017; 1,8-cineole; EJASC 66.922-66.923. • 40; ibid; 15 May. 2017; methyl salicylate; EJASC 66.970-66.973. • 3수; ibid; 15 May. 2017; 1,8-cineole; EJASC 66.974-66.976. • 4ก; ibid; 16 May. 2017; methyl salicylate; EJASC 66.977-66.980. • 1ठ̂; ibid; 16 May. 2017; 1,8-cineole; EJASC 66.981. • 5ð⿱; ibid; 17 May. 2017; methyl salicylate; EJASC 66.982-66.986. • 2ð⿱ ; ibid; 17 May. 2017; 1,8-cineole; EJASC 66.987-66.988. • 10̄; ibid; 20 Jun. 2017; methyl salicylate; EJASC 67.989. • 1ठ̊;; ibid; 24 Jul. 2017; methyl salicylate; EJASC 67.990. • 8ठ̄; ibid; 24 Jul. 2017; 1,8-cineole; EJASC 67.991-67.998. • 1ð̄; ibid; 25 Jul. 2017; methyl salicylate; EJASC 67.999. • $3 \hat{0}$; ibid; 25 Jul. 2017; 1,8-cineole; EJASC 68.000-68.002.・1ð̄; ibid; 28 Aug. 2017; methyl salicylate; EJASC 68.003. • 3 3 ; ibid; 28 Aug. 2017; 1,8-cineole; EJASC 68.004-68.006. • 93; Ibid; 29 Aug. 2017; methyl salicylate; EJASC 68.01768.025. - 2ð; ibid; 29 Aug. 2017; methyl salicylate; EJASC 68.026-68.027. • 50̄; ibid; 25 Sep. 2017; methyl salicylate; EJASC 68.080-68.084. • 8 $0^{\lambda}$; ibid; 25 Sep. 2017; 1,8-cineole; EJASC 68.085-68.092. • 6ð̄; ibid; 26 Sep. 2017; methyl salicylate; EJASC 68.093-68.098. • 7ふै; ibid; 26 Sep. 2017; 1,8-cineole; EJASC 68.09968.105. 4 4 ${ }^{7}$; ibid; 27 Sep. 2017; methyl salicylate; EJASC 68.106-68.109. • 2今; ibid; 26 Oct. 2017; methyl salicylate; EJASC 68.200-68.201. • 9つ̂; ibid; 26 Oct. 2017; 1,8-cineole; EJASC 68.202-68.210. • 4ð’; ibid; 13 Nov. 2017; methyl salicylate; EJASC 68.303-68.306. • 3ð; ibid; 13 Nov. 2017; 1,8-cineole; EJASC 68.307-68.309. • 23; ibid; 12 Dec. 2017; methyl salicylate; EJASC 68.31068.311. - 2万; ibid; 12 Dec. 2017; 1,8-cineole; EJASC 68.312-68.313. • 3̧े; ibid; 22 Jan. 2018; methyl salicylate; EJASC 80.484-80.486. • 3ठో; ibid; 22 Jan. 2018; 1,8-cineole; EJASC 80.487-80.489. • 5ð⿱; ibid; 23 Jan. 2018; methyl salicylate; EJASC 80.490-80.494. • 3今'; ibid; 23 Jan. 2018; 1,8-cineole; EJASC 80.495-80.497. •

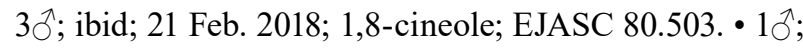
ibid; 20 Feb. 2018; 1,8-cineole; EJASC 80.498. • 4ð; ibid; 20 Feb. 2018; methyl salicylate; EJASC 80.499-80.502. • $2{ }^{3}$; ibid; 7 Mar. 2018; methyl salicylate; EJASC 80.50480.505. • 1今ं; ibid; 9 Mar. 2018; 1,8-cineole; EJASC 80.537. • 6今̄; ibid; 8 Mar. 2018; methyl salicylate; EJASC 80.530-80.535. • 1ð̄; ibid; 8 Mar. 2018; 1,8-cineole; EJASC 80.536. • 3ठ̂;; ibid; 23 Apr. 2018; 1,8-cineole;
EJASC 80.545-80.547. • 4ð̋; ibid; 24 Apr. 2018; 1,8-cineole; EJASC 80.548-80.551. • 1ठ̋; ibid; 24 Apr. 2018; methyl salicylate; EJASC 80.552. • 1ठ઼; Ibid; 28 May 2018; methyl salicylate; EJASC 80.553. • 3ð̄; Ibid; 28 May 2018; 1,8-cineole; EJASC 80.554-80.556. • 1ठ; ibid; 29 May 2018; methyl salicylate; EJASC 80.557. • 15今̄; Ibid; 29 May 2018; 1,8-cineole; EJASC 80.55880.572. • 1ð; ibid; 30 May 2018; 1,8-cineole; EJASC 80.573. • 3今̄; ibid; 25 Jun. 2018; 1,8-cineole; EJASC 80.577-80.579. • 2ð; ibid; 25 Jun. 2018; methyl salicylate; EJASC 80.580-80.581. • 2ð; ibid; 26 Jun. 2018; methyl salicylate; EJASC 80.592-80.593. • 1今̄; ibid; 27 Jun. 2018; 1,8-cineole; EJASC 80.600. - Pantanal wetland $\cdot 6 \hat{\circ}$; Mato Grosso, Cáceres, Periquitos Bay, Paraguay river in the urban area; $16.0223^{\circ} \mathrm{S}, 057.6656^{\circ} \mathrm{W}$; $120 \mathrm{~m}$ a.s.l.; 10 Jun. 2010; Felix A leg.; 1,8-cineole; Wetlands; EJASC 30.700-30.705. - Amazon-Cerrado transition zones - $1 \delta^{\Uparrow}$; Mato Grosso, Pontes e Lacerda, Rio Guaporé; $15.2334^{\circ} \mathrm{S}, 059.3285^{\circ} \mathrm{W} ; 230 \mathrm{~m}$ a.s.1.; 28 Nov. 2007; 1,8-cineole; gallery forest; EJASC 20.157. •

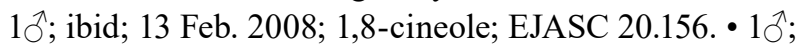
ibid; 12 Aug. 2008; 1,8-cineole; EJASC 20.155. • 20’; Mato Grosso, Reserva do Cabaçal; $15.1131^{\circ} \mathrm{S}$, 058.0847 ${ }^{\circ} \mathrm{W}$; $540 \mathrm{~m}$ a.s.1.; 5 Dec. 2009; Cunha JC leg.; 1,8-cineole; EJASC 27.415-27.416. • $6 \hat{\jmath}$; ibid; 5 Dec. 2009; methyl salicylate; EJASC 27.417-27.422. • 7ðే; ibid; 6 Dec. 2009; methyl salicylate; EJASC 27.40827.414. • 1ठð; ibid; 29 May 2010; methyl salicylate; EJASC 30.249. • 1ठ; ibid; 12 Oct. 2010; 1,8-cineole; EJASC 30.214. • 1ð’; ibid; 4 Sep. 2010; methyl salicylate; EJASC

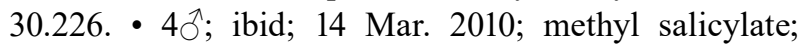
EJASC 30.291-30.294. • 9ð; ibid; 14 Mar. 2010; 1,8-cineole; EJASC 30.282-30.290. • 5つ; ibid; 13 Sep. 2010; methyl salicylate; EJASC 30.221-30.225. ・13ð’; ibid; 31 Jan. 2010; methyl salicylate; EJASC 30.354-30.366. • 10今'; ibid; 31 Jan. 2010; 1,8-cineole; EJASC 30.36630.376. • 3 3 ; Ibid; 13 Mar. 2010; 1,8-cineole; EJASC 30.295-30.297. • 11 ऊ̂; ibid; 13 Mar. 2010; methyl salicylate; EJASC 30.298-30.308. • 30̄; ibid; 25 Sep. 2010; 1,8-cineole; EJASC 30.218-30.220. • 3̧̂;; ibid; 09 Jan. 2010; 1,8-cineole; EJASC 30.398-30.400. • 7ð̊; ibid; 09 Jan. 2010; methyl salicylate; EJASC 30.401-30.407. • 2§ł; ibid; 26 Sep. 2010; 1,8-cineole; EJASC 30.21630.217. • 4ðં; ibid; 10 Jan. 2010; 1,8-cineole; EJASC 30.383-30.386. • 11 ð’; ibid; 10 Jan. 2010; methyl salicylate; EJASC 30.387-30.397. • 20; ibid; 30 Jan. 2010; 1,8-cineole; EJASC 30.377-30.378. • 4ð̊; ibid; 30 Jan. 2010; methyl salicylate; EJASC 30.379-30.382. • 3 ${ }^{\AA}$; ibid; 19 Jun. 2010; 1,8-cineole; EJASC 30.244-30.246. • 1§; ibid; 19 Jun. 2010; methyl salicylate; EJASC 30.247. - 10 ${ }^{\text {; }}$ ibid; 20 Feb. 2010; 1,8-cineole; EJASC 30.32930.338. • 15ડ̄; ibid; 20 Feb. 2010; methyl salicylate; EJASC 30.339-30.353. • 11 ऊ; ibid; 21 Feb. 2010; 1,8-cineole; EJASC 30.309-30.319. • 8ठ; ibid; 21 Feb. 2010; methyl salicylate; EJASC 30.320-30.327. • 1ðَ; ibid; 21 Feb. 2010; Vanillin; EJASC 30.328. - 9ð̊; ibid; 3 Jul. 2010; 1,8-cineole; EJASC 30.227-30.235. • 1ठð; ibid; 3 Jul. 2010; methyl cinnamate; EJASC 30.236. • 7ð̄; ibid; 3 


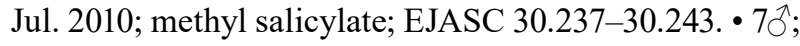
ibid; 22 May 2010; 1,8-cineole; EJASC 30.253-30.259. • 5 §̊; ibid; 22 May 2010; methyl salicylate; EJASC 30.26030.264. • 3ô; ibid; 4 Apr. 2010; 1,8-cineole; EJASC 30.266-30.268.・1ふ; ibid; 4 Apr. 2010; methyl salicylate; EJASC 30.269. • 1ठ̋; ibid; 30 May 2010; 1,8-cineole; EJASC 30.248. • 1ठㅜ; ibid; 29 May 2010; 1,8-cineole; EJASC 30.250. • 20; ibid; 29 May 2010; methyl salicylate; EJASC 30.251-30.252. • 3ठ; ibid; 3 Apr. 2010; 1,8-cineole; EJASC 30.270-30.272. • 9ô; ibid; 3 Apr. 2010; methyl salicylate; EJASC 30.273-30.281. • 1ð̄; ibid; 12 Oct. 2010; 1,8-cineole; EJASC 30.214. •1ð; ibid; 17 Apr. 2010; 1,8-cineole; EJASC 30.265. Amazon rainforest - 3 3 ; Mato Grosso, Cotriguaçu, São Nicolau Farm; $09.8197^{\circ} \mathrm{S}, 058.2587^{\circ} \mathrm{W} ; 230 \mathrm{~m}$ a.s.1.; 23 Aug. 2007; Anjos Silva EJ leg.; methyl salicylate; Preserved forest; EJASC 22.101-22.103. • 2̧^; ibid; 17 Dec. 2010; Anjos Silva EJ leg.; methyl salicylate; EJASC 30.13730.138. - 3ठ; ibid; 11 Dec. 2010; methyl salicylate; EJASC 30.139-30.141. • 6ð’; ibid; 13 Dec. 2012; Schorn de Souza MH leg.; methyl salicylate; EJASC 39.06039.065. • 6ð; ibid; 15 Dec. 2012; Schorn de Souza MH leg.; methyl salicylate; EJASC 39.052-39.057. •1ð̄; ibid; 12 Dec. 2012; Schorn de Souza MH leg.; methyl salicylate; EJASC 39.066. • 1ð̊; ibid; 12 Dec. 2012; Schorn de Souza MH leg.; 1,8-cineole; EJASC 39.067. • 16ð̊; ibid; 27 Oct. 2012; Schorn de Souza MH leg.; methyl salicylate; EJASC 39.096-39.111. • 2ð; ibid; 27 Oct. 2012; Schorn de Souza MH leg.; 1,8-cineole; EJASC 39.112 39.113. • 11ठ; ibid; 28 Oct. 2012; Schorn de Souza MH leg.; methyl salicylate; EJASC 39.082-39.092. • 3ð^; ibid; 28 Oct. 2012; Schorn de Souza MH leg.; 1,8-cineole; EJASC 39.093-39.095. • 11ડ̋; ibid; 25 Oct. 2012; Schorn de Souza MH leg.; methyl salicylate; EJASC 39.12539.135. • 1ðَ; ibid; 25 Oct. 2012; Schorn de Souza MH leg.; 1,8-cineole; EJASC 39.136. • 8ठ; ibid; 26 Oct. 2012; Schorn de Souza MH leg.; methyl salicylate; EJASC 39.114-39.121. • 3ठ; ibid; 26 Oct. 2012; Schorn de Souza MH leg.; 1,8-cineole; EJASC 39.122-39.124. • 10§; ibid; 30 Oct. 2012; Schorn de Souza MH leg.; methyl salicylate; EJASC 39.068-39.077. • 1ठ; ibid; 30 Oct. 2012; Schorn de Souza MH leg.; methyl cinnamate; EJASC 39.078. • 1ðं; ibid; 30 Oct. 2012; Schorn de Souza MH leg.; benzyl acetate; EJASC 39.079. • 2今̄; ibid; 29 Oct. 2012; Schorn de Souza MH leg.; methyl salicylate; EJASC 39.080-39.081. • 7ð̊; ibid; 16 Dec. 2012; Schorn de Souza MH leg.; methyl salicylate; EJASC 39.04539.051. - 20; ibid; 14 Dec. 2012; Schorn de Souza MH leg.; methyl salicylate; EJASC 39.058-39.059. • 2 ${ }_{\text {; }}$; Mato Grosso, Apiacás, Juruena National Park; 09.0493º $\mathrm{S}$, 057.8892 ${ }^{\circ}$ W; 200 m a.s.1.; 8 Aug. 2011; Silva ET leg.; benzyl benzoate; preserved forest; EJASC 35.69035.691 .

Additional materials examined: BRAZIL - Amazon-

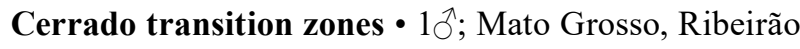
Cascalheira; $12.8624^{\circ} \mathrm{S}, 052.0847^{\circ} \mathrm{W} ; 330 \mathrm{~m}$ a.s.l. 3 Nov. 2011; Junior AJS leg.; 1,8-cineole; EJASC 36.145.
- 3今; Mato Grosso, Novo Mundo, Cristalino State Park; $09.4669^{\circ} \mathrm{S}, 055.8428^{\circ} \mathrm{W} ; 305 \mathrm{~m}$ a.s.l.; 13 May 2013; Figueiredo JDS.; 1,8-cineole; EJASC 40.036-40.038. - 6ðึ; ibid; 13 May 2013; methyl salicylate; EJASC 40.039-40.044. • 3 ; ibid; 17 May 2013; methyl salicylate; EJASC 40.063-40.065. - 1ठ઼; ibid; 17 May 2013; 1,8-cineole; EJASC 40.066. • 6ð̊; ibid; 14 May 2013; methyl salicylate; EJASC 40.027-40.032. - 2今; ibid; 14 May 2013; 1,8-cineole; EJASC 40.033-40.035. • 4 ibid; 15 May 2013; methyl salicylate; EJASC 40.02140.024. • 2今'; ibid; 15 May 2013; 1,8-cineole; EJASC 40.025-40.026. • 4र; ibid; 16 May 2013; methyl salicylate; EJASC 40.049-40.052. - 1ठ; ibid; 12 Dec. 2013; methyl salicylate; EJASC 40.110. • 1ठ̂; Ibid; 14 Dec. 2013; methyl salicylate; EJASC 40.127. • 1ठ; ibid; 14 Dec. 2013; 1,8-cineole; EJASC 40.128. • 1ठ; ibid; 14 Dec. 2013; Vanillin; EJASC 40.129. • 2ð⿱; ibid; 6 Sep. 2014; 1,8-cineole; EJASC 40.071-80.072. • 1ठð; ibid; 4 Sep. 2014; 1,8-cineole; EJASC 42.005. - 1ठ;; ibid; 4 Sep. 2014; methyl cinnamate; EJASC 42.006. • 2ð̂; ibid; 7 Sep. 2014; 1,8-cineole; EJASC 42.021-42.022-42.023. • 1ठ̊; ibid; 5 Sep. 2014; 1,8-cineole; EJASC 42.004.

As a partial result of the survey made over the course of 20 months of collections of euglossines in the São Vicente Range, in the Santo Antônio do Leverger municipality, a total of 295 E. imperialis males were catalogued, of which 171 males (57.97\%) were attracted to methyl salicylate, and 124 males $(42,03 \%)$ to 1,8 -cineole.

Considering all the E. imperialis males deposited in the UNEMAT Bee Collection, a total of 777 males were obtained from 10 municipalities of Mato Grosso, all of them catalogued in the Amazon-Paraguay drainage divide (Figs 1-4).

The majority of the males were attracted to methyl salicylate $(455 \hat{\jmath} ; 58.48 \%)$ and to 1,8 -cineole $(307 \delta$; $39.51 \%)$. Other chemicals, like vanillin $\left(3{ }^{\Uparrow}\right)$, eugenol $\left(6 \delta^{\lambda}\right)$, methyl cinnamate $\left(3 \delta^{\lambda}\right)$, benzyl acetate $\left(1 \delta^{\lambda}\right)$, and benzyl benzoate $(2 \hat{\jmath})$ attracted only 15 males $(1,93 \%)$ of the species in the 10 study areas surveyed (Table 1).

The data presented here are relative to the 777 male specimens of $E$. imperialis collected by our team in 10 municipalities: Apiacás $\left(N=2{ }^{\Uparrow}\right)$, Novo Mundo $(N=$ 43§), Cotriguaçu $(N=100 \AA)$, Ribeirão Cascalheira $(N$ $=1 \hat{\zeta})$, Reserva do Cabaçal $(N=208 \hat{\jmath})$, Pontes e Lacerda $\left(N=3{ }^{\AA}\right)$, Chapada dos Guimarães (Chapada dos Guimarães National Park) $(N=57 \hat{\jmath})$, Porto Estrela (Serra das Araras Ecological Station) $(N=61 \circlearrowleft)$, Santo Antônio do Leverger (São Vicente Range) $(N=295 \AA)$, and Cáceres $\left(N=7 \delta^{\Uparrow}\right)$. All occurrence data of E. imperialis in the Amazon rainforest, Amazon to Cerrado transition zones, Cerrado, and Pantanal of Mato Grosso are shown in Table 1; these occurrence points are all within the Amazon-Paraguay drainage divide (Figs 1-4).

\section{Identification}

Theodore D.A. Cockerell described E. imperialis based on four females from Rio Trinidad, Panama as rich green 
Table 1. Study areas surveyed in 10 municipalities of Mato Grosso state in central-western Brazil. Occurrence points of Euglossa imperialis Cockerell, 1922 in the Amazon-Paraguay drainage divide, with chemicals used as baits and the list of specimens collected during the last 16 years (2002-2018), all of them housed in the UNEMAT Bee Collection (EJASC). Effort refers to active working day collections using entomological net from 8 a.m. to 4 p.m. or refers to the $2 \mathrm{~L}$ bottle trap used in orchid bee baiting programs in the basins since 2002 .

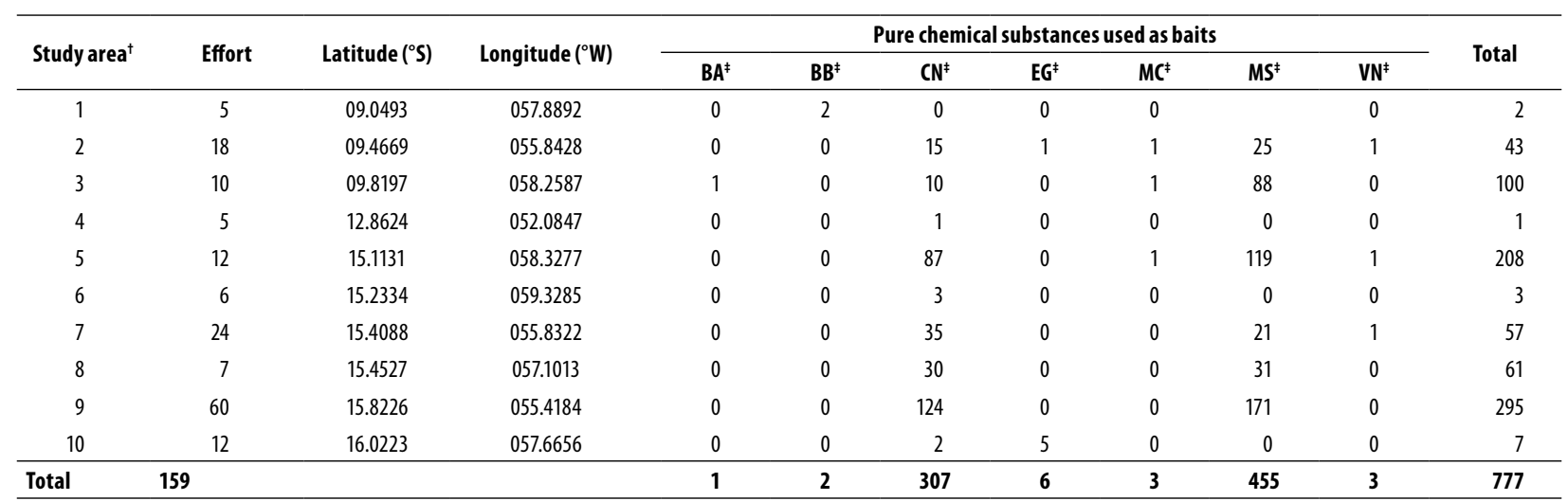

'Study area: 1 = Apiacás, 2 = Novo Mundo, 3 = Cotriguaçu, 4 = Ribeirão Cascalheira, $5=$ Reserva do Cabaçal, $6=$ Pontes e Lacerda, $7=$ Chapada dos Guimarães, 8 = Porto Estrela, 9 = Santo Antônio do Leverger, $10=$ Cáceres.

${ }^{\ddagger}$ Chemical substances: $\mathrm{BA}=$ benzyl acetate, $\mathrm{BB}=$ benzyl benzoate, $\mathrm{CN}=1,8$-cineole, $\mathrm{EG}=$ eugenol, $\mathrm{MC}=$ methyl cinnamate, $\mathrm{MS}=$ methyl salicylate, $\mathrm{VN}=$ vanillin.

and largely uniform in their coloration, yet appearing brilliant purple when seen in direct light. The broad hind margin of the first segment of the intense purple abdomen is the other feature in his original descriptions for the species (type: USNM 24882, March 16-23, 1912) (Cockerell 1922: 6). Extremely elongated mouthparts, which extend far beyond the apex of abdomen, were another feature he later added for the species (Cockerell 1917: 144).

The 777 males were identified based on the original descriptions and the illustrated keys by Rebêlo and Moure (1995). Comparisons were also made with specimens housed in the EJASC (LABEVE). The last revision made by Faria Junior and Melo (2007) was used to check the status of the species and the geographic distribution records.

The rich green coloration of the bees collected in the Amazon-Paraguay basins do not differ from that originally described for the females (Fig. 4), but there are no brilliant purple highlights on the abdomen as indicated by Cockerell (1922).

One should note the evident colour variation in the teguments when comparing the populations from Mato Grosso and Mato Grosso do Sul, varying from the dark green metallic coloration on the face and body of the males from the Amazon-Paraguay divide (Fig. 4) (e.g., Anjos-Silva 2006b; Anjos-Silva 2011; Figueiredo et al. 2015; this study), to the intense metallic blue with some green highlights observed in the populations of the Mato Grosso do Sul Cerrado (Henrique et al. 2018: 1062, figs $1,4)$.

\section{Discussion}

After the publication by Henrique et al. (2018) in which they record 34 males of E. imperialis in two Cerrado fragments in Nova Alvorada do Sul municipality, Mato
Grosso do Sul, Brazil, we decided to review the literature and publish the data produced by our laboratory in recent years, with the aim of eliminating the biogeographical gaps for the species in the Amazon-Paraguay drainage divide.

With vast geographical distribution throughout the Neotropics, E. imperialis has been recorded from southern Mexico, and possibly Jamaica (Roubik 2004), to the Amazon forest and Cerrado domains in mid-west Brazil, the fragmented areas of the Cerrado, and the Atlantic forest in southern Brazil (Rebêlo and Moure 1995; Oliveira and Campos 1996; Rebêlo and Garófalo 1997; Silva and Rebêlo 1999; Roubik 2004; Anjos-Silva 2006a, 2006b, 2011; Moure et al. 2012; Figueiredo et al. 2015; McCravy et al. 2016; Antonini et al. 2017; Tosta et al. 2017; Cândido et al. 2018; Coswosk et al. 2018; Henrique et al. 2018; Machado et al. 2018; Padrón et al. 2018).

Males from Central America, the Amazon basin, and Atlantic forest regions were examined by Faria Junior and Melo (2007), but no differences in the morphological features were found between populations.

Rebêlo and Moure (1995) suggested that the absence of this species in Central Brazil is an artefact due to the lack of collections. According to Rebêlo (2001), the penetration of E. imperialis into southern South America might be related to introgression into the tropical forest along the Atlantic coast, or an old continuity through the northern portion of the Brazilian Planalto Central.

Although Brito et al. (2017) suggested that this species is highly associated with forest habitats, it is known to occur in areas within the Cerrado domain (Rebêlo and Moure 1995; Rebêlo and Garófalo 1997; Nemésio and Faria Junior 2004; Henrique et al. 2018), and it is frequently reported in gallery forests (Anjos-Silva 2006a; Silveira et al. 2015), which may act as biodiversity corridors (Moura and Schlindwein 2009).

The study area for our surveys is in the municipality 
of Santo Antônio do Leverger, in the São Vicente Range, and inserted in a gallery forest located precisely between the Paraguay and the Araguaia basins and approximately $27 \mathrm{~km}$ from the flood plains of the Cuiabá river, where the Cerrado domains is the dominant landscape.

The abundance of $E$. imperialis males in the area surveyed from 2016 to 2018 in São Vicente Range ( $N=$ 295 ) ) was notably higher when compared to other site collections studied over the last 16 years (2002-2018) in Mato Grosso, varying from just a single male catalogued in the Xingu basin (Oliveira-Junior et al. 2015) to 208 males collected near the Monte Cristo waterfall in the Reserva do Cabaçal municipality, near Bolivia.

Both in the printed version (Moure et al. 2007) and in the online version (Moure et al. 2012), Moure et al. did not record E. imperialis from Mato Grosso. Only two records, one from Xingu basin (Oliveira-Junior et al. 2015) and the other from the Tapajós river (Figueiredo et al. 2015), were cited by Henrique et al. (2018).

The single male captured in the transition zones between the Amazon and Cerrado areas in Ribeirão Cascalheira (Oliveira-Junior et al. 2015) could lead to misinterpretation and to the conclusion that E. imperialis is a rare species in the Cerrado domain or even in the transition zones in the basins.

For the first time, we document $E$. imperialis from the Pantanal wetland areas, which are inundated by the Cuiabá river, a tributary of the Paraguay river, in the Pantanal of Cáceres, and in the Periquitos bay, in the urban area. The occurrence point of E. imperialis in the Cerrado of Nova Alvorada do Sul is roughly $100 \mathrm{~km}$ from Campo Grande, the capital of Mato Grosso do Sul, only $150 \mathrm{~km}$ from Paraná state, and approximately $700 \mathrm{~km}$ from Pantanal of Cáceres to the north.

In addition to including the previous records of this species in Mato Grosso, the Tapajós river basin (Figueiredo et al. 2015), and Xingu (Oliveira-Junior et al. 2015) cited by Henrique et al. (2018), our paper adds eight new records from the Amazon forest, Amazon to Cerrado transitions, Cerrado, and Pantanal of Mato Grosso. Our collections (this study) add a series of males collected in Apiacás, Cotriguaçu, Pontes e Lacerda, Reserva do Cabaçal, Cáceres, Porto Estrela, Santo Antônio do Leverger, Chapada dos Guimarães, all of them obtained in the Amazon-Paraguay drainage divide.

Ramirez et al. (2010) observed recurrent range splits connecting the Amazon and the Paraguayan Corridor, the Amazon and the Atlantic Forest, and the Amazon and the Andes. The Amazon region has the highest species diversity (68 species), and the Paraguayan Corridor the lowest (17 species). Euglossa imperialis has recently been sampled along latitudinal gradients of tropical, evergreen forests in central Bolivia at Vila Tunari $\left(18^{\circ} 57^{\prime} 59^{\prime \prime} \mathrm{S}\right.$, $\left.065^{\circ} 24^{\prime} 44^{\prime \prime} \mathrm{W}\right)$, Sacta $\left(17^{\circ} 06^{\prime} 03^{\prime \prime} \mathrm{S}, 064^{\circ} 47^{\prime} 02^{\prime \prime} \mathrm{W}\right)$, and Buena Vista $\left(17^{\circ} 30^{\prime} 49^{\prime \prime} \mathrm{S}, 063^{\circ} 38^{\prime} 16^{\prime \prime} \mathrm{W}\right)$ (Abrahamczyk et al. 2012). Curiously, this species has not been recorded in the dry forests of the mid-south of Mato Grosso state, Brazil (Água Milagrosa sinkhole and Jacobina Farm;
Anjos-Silva 2006) and in central Bolivia (Santa Cruz and Rio Seco; Abrahamczyk et al. 2012), which possibly indicates a preference for humid rather than dry habitats. However, with the addition of the new record for Bolivia (Abrahamczyk et al. 2012) and new and old records presented here, it is possible that the species uses gallery forests from the Amazon to the Cerrado to reach the Atlantic forest domains (see Ab'Sáber 1971), as previously document for Eulaema cingulata (Fabricius, 1804) (Anjos-Silva 2006a, 2006b, 2007) and Euglossa cognata Moure, 1970 (Anjos-Silva 2008). In this scenario, the male populations of $E$. imperialis possibly use the Pantanal wetland and the gallery forest as ecological corridors from the central Bolivian Amazon domain to reach the southeast and the Atlantic forest in Brazil (Rebêlo and Garófalo 1991, 1997; Rebêlo 2001; Ramirez et al. 2010; Mateus et al. 2015).

\section{Acknowledgements}

Support was provided by FAPEMAT (project numbers 334721/2008, 737955/2012, 222842/2015), INCT/ CENBAM/PPBio/ UFMT/UNEMAT to MH Schorn de Sousa, and INCT PPBIO/MPEG/UNEMAT to EJAS. We thanks Marlúcia B. Martins (MPEG/MCT/CNPq/ INPP) for support during the Apiacás project. We also thanks Jaquison C. Cunha, Sandro O. Pains, Felix A. Labaig, and Jessica DS Figueiredo for the help during collections, and Mariana T. Brito for the map design. Two reviewers provided useful comments on an early version on the manuscript.

\section{Authors' Contributions}

EJAS conceived, designed, and performed the study. EJAS and MHSS (Cotriguaçu and Santo Antônio do Leverger) performed the research and interpretation of the data and both authors wrote the paper.

\section{References}

Abrahamczyk S, Gottleuber P, Kessler M (2012) Seasonal changes in odour preferences by male euglossine bees (Hymenoptera: Apidae) and their ecological implications. Apidologie 43: 212-217. http://do.org/10.1007/s13592-011-0096-7

Ackerman JD (1983) Diversity and seasonality of male Euglossine bees (Hymenoptera: Apidae) in Central Panamá. Ecology 64: 274-283. https://doi.org/10.2307/1937075

Anjos-Silva EJ (2006a) Fenologia das abelhas Euglossini Latreille (Hymenoptera: Apidae) e a variação sazonal e geográfica na escolha e preferência por iscas-odores no Parque Nacional de Chapada dos Guimarães e na Província Serrana de Mato Grosso, Brasil. PhD dissertation, Universidade de São Paulo, Ribeirão Preto, 127 pp.

Anjos-Silva EJ (2006b) Orchid bee species from Mato Grosso: an appraisal. Anais do VII Encontro sobre Abelhas, pp. 503-509 (CD-ROM), Ribeirão Preto, 12-15 de julho.

Anjos-Silva EJ (2007) Occurrence of Eulaema (Apeulaema) pseudocingulata Oliveira (Hymenoptera: Apidae: Euglossini) in the Platina Basin, Mato Grosso state, Brazil. Neotropical Entomology 36 (3): 484-486. https://doi.org/10.1590/S1519-566X20070 00300022) 
Anjos-Silva EJ (2008) Discovery of Euglossa (Euglossa) cognata Moure (Apidae: Euglossini) in the Platina Basin, Mato Grosso state, Brazil. Biota Neotropica 8 (2): 79-83.

Anjos-Silva EJ (2011) Abelhas Euglossini (Anthophila: Hymenoptera: Apidae) nas margensdo Rio Juruena: check list das espécies na Floresta Amazônica em Cotriguaçu (Mato Grosso), incluindo chave ilustrada para Exaerete. In: Rodrigues DJ, Izzo TJ, Battirola LD (Eds) Descobrindo a Amazônia Meridional: Biodiversidade da Fazenda São Nicolau. Pau e Prosa Comunicação Ltda, Cuiabá, 51-73.

Antonini Y, Machado CB, Galetti PMJr, Oliveira M, Dirzo R, Fernandes GW (2017) Patterns of orchid bee species diversity and turnover among forested plateaus of central Amazonia. PLoS ONE 12 (4): 1-16. e0175884. https://doi.org/10.1371/journal.pone.0175884

Becker P, Moure JS, Peralta FJA (1991) More about euglossine bees in Amazonian forest fragments. Biotropica 23 (4): 586-591. https:// doi.org/10.2307/2388396

Brito TF, Phifer CC, Kowlton JL, Fiser CM, Becker NM, Barros FC, Contrera AL, Maués MM, Juen L, Montag LFA, Webster CR, Flaspohler DJ, Santos PD, Silva DP (2017) Forest reserves and riparian corridors help maintain orchid bee (Hymenoptera: Euglossini) communities in oil palm plantations in Brazil. Apidologie 48: 575-587. https://doi.org./10.1007/s13592-017-0500-z

Cândido MEMB, Morato EF, Storck-Tonon D, Miranda PN, Vieira LJS (2018) Effects of fragments and landscape characteristics on the orchid bee richness (Apidae: Euglossini) in an urban matrix, southwestern Amazonia. Journal of Insect Conservation 22: 475486. https://doi.org/10.1007/s10841-018-0075-7

Cockerell TDA (1917) Some euglossine bees. The Canadian Entomologist 49 (4): 144-146. https://doi.org/10.4039/Ent49144-4

Cockerell TDA (1922) Bees in the collection of the United States Museum. Proceedings of the United States National Museum 60 (2413): 1-20. https://doi.org/10.5479/si.00963801.60-2413.1

Coswosk JA, Ferreira RA, Soares EDG, Faria LRR (2018) Responses of euglossine bees (Hymenoptera, Apidae, Euglossina) to an edge-forest gradient in a large tabuleiro forest remnant in eastern Brazil. Neotropical Entomology 47: 447-456. https://doi.org/10 1007/s13744-017-0533-z

Darrault RO, Medeiros P, Locatelli E, Lopes AV, Schlindwein C (2005) Abelhas Euglossini (Hymenoptera Apidae) no centro de endemismo Pernambuco. In: Pôrto K, Almeida-Cortez J, Tabarelli M (Eds) Diversidade Biológica e Conservação da Floresta Atlântica ao Norte do Rio São Francisco. Ministério do Meio Ambiente, Brasília, 239-256.

Dressler RL (1978) An infrageneric classification of Euglossa, with notes on some features of special taxonomic importance (Hymenoptera, Apidae). Revista de Biología Tropical 26: 187-198.

Engel M (1999) The first fossil Euglossa and phylogeny of the orchid bees (Hymenoptera: Apidae; Euglossini). American Museum Novitates 3272: 1-14.

Engel M (2001) A monograph of the Baltic amber bees and evolution of the Apoidea (Hymenoptera). Bulletin of the American $\mathrm{Mu}-$ seum of Natural History 259: 1-192.

Eltz T, Whitten WM, Roubik DW, Linsenmair KE (1999) Fragrance collection, storage, and accumulation by individual male Orchid bees. Journal of Chemical Ecology 25:157-176. https://doi org/10.1023/A:1020897302355

Faria Junior LRR, Melo GAR (2007) Species of Euglossa (Glossura) in the Brazilian Atlantic forest, with taxonomic notes on Euglossa stellfeldi Moure (Hymenoptera, Apidae, Euglossina). Revista Brasileira de Entomologia 51: 275-284. https://doi.org/10.1590/ S0085-56262007000300004

Figueiredo JDS, Schorn de Souza MH, Anjos-Silva EJ (2015) Abelhas-das-orquídeas. In: Rodrigues DJ, Noronha JC, Vindica VF, Barbosa FR (Eds) Biodiversidade do Parque Estadual Cristalino. Áttema Editorial, Sinop, 96-109.

Hinojosa-Díaz IA, Engel MS (2012a) Alloglossura, a new subgenus of the orchid bee genus Euglossa (Hymenoptera: Apidae), with a review of the included species. Scientific Papers, Natural History Museum, University of Kansas 45: 1-37.

Hinojosa-Díaz IA, Engel MS (2012b) A checklist of the orchid bees of Nicaragua (Hymenoptera: Apidae: Euglossini). Journal of the Kansas Entomological Society 85 (2): 135-144. https://doi.org/10. 17161/jom.v0i36.4777

Henrique JA, Sobreiro AI, Alves Júnior VV (2018) First record of the orchid bee Euglossa imperialis Cockerell, 1922 (Hymenoptera, Apidae, Euglossina) in Mato Grosso do Sul state, midwestern Brazil. Check List 14 (6): 1059-1064. https://doi.org/ 10.15560/14.6.1059

Janzen DH, deVries PJ, Higgins ML, Kimsey LS (1982) Seasonal and site variation in Costa Rican euglossine bees at chemical baits in lowland deciduous and evergreen forests. Ecology 63 (1): 66-74. https://doi.org/10.2307/1937032

Machado CAS, Costa CP, Francoy TM (2018) Different physiognomies and the structure of Euglossini bee (Hymenoptera: Apidae) communities. Sociobiology 65 (3): 471-481. https://doi.org/10.13 102/sociobiology.v65i3.2718

Mateus S, Andrade-Silva ACR, Garófalo CA (2015) Diversity and temporal variation in the orchid bee community (Hymenoptera: Apidae) of a remnant of a Neotropical seasonal semi-deciduous forest. Sociobiology 62 (4): 571-577. https://doi.org/10.13102/sociobiology. v62i4.391

Michener CD (2007) The bees of the world. 2nd edition The John Hopkins University Press, Baltimore, USA, 953 pp.

McCravy KW, Dyke JV, Creedy TJ, Roubik DW (2016) Orchid bees (Hymenoptera: Apidae: Euglossini) of Cusuco National Park, state of Cortés, Honduras. Florida Entomologist 99: 765-768. https://doi .org/10.1653/024.099.0431

Moura DC, Schlindwein C (2009) Mata Ciliar do Rio São Francisco como biocorredor para Euglossini (Hymenoptera: Apidae) de Florestas Tropicais Úmidas. Neotropical Entomology 38: 281284. https://doi.org/10.1590/S1519-566X2009000200018

Moure JS (1989) Glossuropoda, novo subgênero de Euglossa, e duas espécies novas da Amazônia, do mesmo subgênero (Apidae-Hymenoptera). Memórias do Instituto Oswaldo Cruz 84: 387-389. https://doi.org/10.1590/S0074-02761989000800069

Moure JS, Melo GAR, Faria LRR (2007) Euglossini Latreille, 1802. In: Moure JS, Urban D, Melo GAR (Eds) Catalogue of bees (Hymenoptera, Apoidea) in the Neotropical Region. Sociedade Brasileira de Entomologia, Curitiba, 238-241.

Moure JS, Melo GAR, Faria Jr. LRR (2012) Euglossini Latreille, 1802. In: Moure JS, Urban D, Melo GAR (Eds) Catalogue of bees (Hymenoptera, Apoidea) in the Neotropical Region. Online version. http:// moure.cria.org.br/catalogue?id=31315. Accessed on: 2019-4-10.

Nemésio A, Faria Junior LRR (2004) First assessment of the orchidbee fauna (Hymenoptera: Apidae) at Parque Estadual do Rio Preto, a Cerrado area in southeastern Brazil. Lundiana 5: 113-117.

Oliveira ML, Campos LAO (1996) Preferência por estratos florestais e por substâncias odoríferas em abelhas Euglossinae (Hymenoptera, Apidae). Revista Brasileira de Zoologia 13: 1075-1085. https://doi.org/10.1590/S0101-81751996000400025

Oliveira ML, Silva SJR, Silva MC, Araújo OCO, Albuquerque MIC, Tavares SF (2010) Abelhas de Roraima: por que tantas espécies em tão pouco espaço? In: Barbosa RI, Melo VF (Eds) Homem, Ambiente e Ecologia. Femact, Boa vista, 523-540.

Oliveira-Junior JMB, Almeida SM, Rodrigues L, Silvério Júnior AJ, Anjos-Silva EJ (2015) Orchid bees (Apidae: Euglossini) in a forest fragment in the ecotone Cerrado-Amazonian forest, Brazil. Acta Biológica Colombiana 20: 67-78. https://doi.org/10.15446/ abc.v20n3.41122

Otero TJ, Sandino JC (2003) Capture rates of male euglossine bees across a human intervention gradient, Chocó Region, Colombia. Biotropica 35: 520-529. https://doi.org/10.1111/j.1744-7429.2003. tb00608.x

Padrón PS, Roubik DW, Picón RP (2018) A preliminary checklist of the orchid bees (Hymenoptera: Apidae: Euglossini) of Ecuador. 
Psyche 2018: 2678632. https://doi.org/10.1155/2018/2678632

Peel MC, Finlayson BL, Mcmahon TA (2007) Updated world map of the Köppen-Geiger climate classification. Hydrology and Earth System Sciences 4: 439-493. https://doi.org/10.5194/hess-11-16332007

Ramírez S, Dressler RL, Ospina M (2002) Abejas euglosinas (Hymenoptera: Apidae) de la Región Neotropical: listado de especies con notas sobre su biología. Biota Colombiana 3 (1): 7-118.

Ramírez SR, Roubik DW, SKOV C, Pierce, NE (2010) Phylogeny, diversification patterns and historical biogeography of euglossine orchid bees (Hymenoptera: Apidae). Biological Journal of the Linnean Society, 100: 552-572. https://doi:10.1111/j.10958312.2010.01440.x

Rebêlo JMM (2001) História natural das euglossíneas: as abelhas das orquídeas. Lithograf, São Luís, 152 pp.

Rebêlo JMM, Garófalo CA (1991) Diversidade e sazonalidade dos machos de Euglossini (Hymenoptera: Apidae) e preferências por iscas-odores em um fragmento de floresta no sudeste do Brasil. Revista Brasileira de Biologia 51: 787-799.

Rebêlo JMM, Garófalo CA (1997) Comunidade de machos de Euglossini (Hymenoptera: Apidae) em matas semideciduais do nordeste do estado de São Paulo. Anais da Sociedade Entomológica do Brasil 23: 243-255. https://doi.org/10.1590/S0301-80591997000 200005

Rebêlo JMM, Moure JS (1995) As espécies de Euglossa Latreille do Nordeste de São Paulo (Apidae, Euglossinae). Revista Brasileira de Zoologia 12: 445-466. https://doi.org/10.1590/S0101-81751995 000300001

Rebêlo JMM, Silva FS (1999) Distribuição das abelhas Euglossini (Hymenoptera: Apidae) no Estado do Maranhão, Brasil. Anais da Sociedade Entomológica Brasileira 28 (3): 389-401. https://doi.
org/10.1590/S0301-80591999000300003

Roubik DW (1993) Tropical pollinators in the canopy and understory: field data and theory for stratum preferences. Journal of Insect Behavior 6: 656-673. https://doi.org/10.1007/BF01201668

Roubik DW (2004) Sibling Species of Glossura and Glossuropoda in the Amazon region (Hymenoptera: Apidae: Euglossini). Journal of the Kansas Entomological Society 77: 235-253. https://oi.org/ 10.2317/0308.20.1

Roubik DW, Hanson PE (2004) Orchid bees from tropical America: biology and field guide. INBio Press, Santo Domingo de Heredia, $352 \mathrm{pp}$.

Schorn de Souza MH (2014) Estrutura e composição da comunidade de abelhas Euglossini atraídas por iscas artificiais na Amazônia Meridional, Brasil. Master's thesis, Universidade Federal de Mato Grosso, Sinop, 68 pp.

Silva FS, Rebêlo JMM (1999) Euglossine bees (Hymenoptera: Apidae) of Buriticupu, Amazônia of Maranhão, Brazil. Acta Amazonica 29: 587-599. https://doi.org/10.1590/1809-43921999294599

Silveira GC, Freitas RF, Tosta THA, Rabelo LS, Gaglianone MC, Augusto SC (2015) The orchid bee fauna in the Brazilian savanna: do forest formations contribute to higher species diversity? Apidologie 46: 197-208. https://doi.org/10.1007/s13592-014-0314-1

Tosta THA, Silveira GC, Schiavinia I, Sofia SH, Augusto SC (2017) Using short-term surveys and mark-recapture to estimate diversity and population size of orchid bees in forest formations of the Brazilian savanna. Journal of Natural History 51 (7-8): 391-403. https://doi.org/10.1080/00222933.2016.1274441

Zimmerman JK, Madriñan SR (1988) Age structure of male Euglossa imperialis (Hymenoptera: Apidae: Euglossini) at nectar and chemical sources in Panama. Journal of Tropical Ecology 4 (3): 03-06. https://doi.org/10.1017/S0266467400002868 